\title{
Effects of the novel (Pro3)GIP antagonist and exendin(9-39)amide on GIP- and GLP-1-induced cyclic AMP generation, insulin secretion and postprandial insulin release in obese diabetic (ob/ob) mice: evidence that GIP is the major physiological incretin
}

\author{
V. A. Gault ${ }^{1}$, F. P. M. O’Harte ${ }^{1}$, P. Harriott ${ }^{2}$, M. H. Mooney ${ }^{1}$, B. D. Green ${ }^{1}$, P. R. Flatt ${ }^{1}$ \\ ${ }^{1}$ School of Biomedical Sciences, University of Ulster, Coleraine, Northern Ireland, United Kingdom \\ 2 Centre for Peptide and Protein Engineering, School of Biology and Biochemistry, The Queen's University of Belfast, \\ Medical Biology Centre, Belfast, Northern Ireland, United Kingdom
}

\section{Abstract}

Aims/hypothesis. This study examined the biological effects of the GIP receptor antagonist, $\left(\mathrm{Pro}^{3}\right)$ GIP and the GLP-1 receptor antagonist, exendin(9-39)amide.

Methods Cyclic AMP production was assessed in Chinese hamster lung fibroblasts transfected with human GIP or GLP-1 receptors, respectively. In vitro insulin release studies were assessed in BRIN-BD11 cells while in vivo insulinotropic and glycaemic responses were measured in obese diabetic $(o b / o b)$ mice.

Results. In GIP receptor-transfected fibroblasts, $\left(\mathrm{Pro}^{3}\right)$ GIP or exendin(9-39)amide inhibited GIP-stimulated cyclic AMP production with maximal inhibition of $70.0 \pm 3.5 \%$ and $73.5 \pm 3.2 \%$ at $10^{-6} \mathrm{~mol} / \mathrm{l}$, respectively. In GLP-1 receptor-transfected fibroblasts, exendin(9-39)amide inhibited GLP-1-stimulated cyclic AMP production with maximal inhibition of $60 \pm 0.7 \%$ at $10^{-6} \mathrm{~mol} / \mathrm{l}$, whereas $\left(\mathrm{Pro}^{3}\right)$ GIP had no effect. (Pro ${ }^{3}$ GIP specifically inhibited GIP-stimulated insulin release $(86 \% ; p<0.001)$ from clonal BRIN-BD11 cells, but had no effect on GLP-1-stimulated insulin release. In contrast, exendin(9-39)amide inhibited both GIP and GLP-1-stimulated insulin release $(57 \%$ and $44 \%$, respectively; $p<0.001)$. Administration of $\left(\mathrm{Pro}^{3}\right) \mathrm{GIP}$, exendin(9-39)amide or a combination of both peptides $(25 \mathrm{nmol} / \mathrm{kg}$ body weight, i.p.) to fasted (ob/ob) mice decreased the plasma insulin responses by $42 \%$, $54 \%$ and $49 \%$, respectively $(p<0.01$ to $p<0.001)$. The hyperinsulinaemia of non-fasted $(o b / o b)$ mice was decreased by $19 \%, 27 \%$ and $18 \%(p<0.05$ to $p<0.01)$ by injection of $\left(\mathrm{Pro}^{3}\right) \mathrm{GIP}$, exendin(9-39)amide or combined peptides but accompanying changes of plasma glucose were small.

Conclusions/interpretation. These data show that $\left(\mathrm{Pro}^{3}\right)$ GIP is a specific GIP receptor antagonist. Furthermore, feeding studies in one commonly used animal model of obesity and diabetes, $(o b / o b)$ mice, suggest that GIP is the major physiological component of the enteroinsular axis, contributing approximately $80 \%$ to incretin-induced insulin release. [Diabetologia (2003) 46:222-230]

Keywords Enteroinsular axis, GIP receptor antagonist, glucagon-like peptide-1, glucose-dependent insulinotropic polypeptide, insulin release.
Received: 24 June 2002 / Revised: 10 September 2002

Published online: 12 February 2003

(C) Springer-Verlag 2003

Corresponding author: P. R. Flatt, School of Biomedical Sciences, University of Ulster, Cromore Road, Coleraine, BT52 1SA Northern Ireland, United Kingdom

E-mail: pr.flatt@ulster.ac.uk

Abbreviations: DPA, diprotin A; ESI-MS, electrospray ionisation-mass spectrometry; GIP, glucose-dependent insulinotropic polypeptide; GLP-1, glucagon-like peptide-1-(7-36)amide; TFA, trifluoroacetic acid.
The insulin secretory activity of pancreatic beta cells can be modulated in both a positive or negative manner by several peptide hormones and neurotransmitters $[1,2,3]$. The two intestinal hormones, glucosedependent insulinotropic polypeptide (GIP) and glucagon-like peptide-1-(7-36)amide (GLP-1) have long been recognised as potent stimulators of insulin secretion under physiological conditions, and for that reason they are considered important incretin hormones $[4,5,6]$. The effects of both GIP and GLP-1 are glucose-dependent, providing a safeguard against potentially hazardous hypoglycaemic episodes, and as a 
consequence of their actions on glucose homeostasis they have been proposed as potential agents for Type 2 diabetes therapy $[7,8,9,10]$.

Although both GIP and GLP-1 possess significant insulinotropic activity, some controversy exists as to their relative physiological roles in stimulating insulin release in response to feeding. Several reports have shown that both GIP and GLP-1 are equipotent in stimulating insulin secretion $[11,12]$ whereas others have suggested that GLP-1 possesses greater insulinotropic activity $[13,14]$. The interpretation that GLP-1 is the more important incretin hormone stems very largely from studies using exendin(9-39)amide, a GLP-1-like peptide isolated from the venom of Heloderma suspectum [15]. Several reports have shown that exendin(9-39)amide is an antagonist of both rat and human GLP-1 receptors [16, 17]. Therefore, exen$\operatorname{din}(9-39)$ amide has been used to assess the specific role of GLP-1 in the regulation of meal-induced insulin release and blood glucose homeostasis both in animals and humans $[18,19,20,21]$. In human studies, exendin(9-39)amide has been shown to antagonise the action of GLP-1 but high concentrations are needed $[20,21]$. The countering ability is evidently less potent than in the rat, in which exendin(9-39)amide is effective at 30 to 100 times the concentration of GLP-1 [16, 18].

Other studies using exendin(9-39)amide have shown that the antagonist could additionally inhibit GIP receptor binding and GIP-stimulated cAMP production $[22,23]$. Therefore, it seems likely that the in vivo antagonistic actions of exendin(9-39)amide are not merely confined to the GLP-1 receptor and that functional ablation of GIP contributes to the observed effects of exendin(9-39)amide. This view is further supported by recent studies in transgenic animals where the GIP and GLP-1 receptors have been disrupted. Studies in GLP-1 receptor knockout mice have attributed lack of disturbances in glucose homeostasis to compensatory enhancement in the secretion and insulinotropic action of GIP [24]. In contrast, studies with GIP receptor knockout mice have shown that these animals have clear disturbances in glucose homeostasis, with higher blood glucose concentrations and impaired first phase insulin response [25].

In order to assess the role of GIP as a physiological incretin, our laboratory has recently developed an enzyme-resistant GIP receptor antagonist, $\left(\mathrm{Pro}^{3}\right)$ GIP [26]. In this study, we have examined the relative specificities of $\left(\mathrm{Pro}^{3}\right)$ GIP and exendin(9-39)amide as antagonists for GIP and GLP-1-stimulated cAMP generation and insulin secretion. Furthermore, we have investigated the effects of $\left(\mathrm{Pro}^{3}\right) \mathrm{GIP}$, exendin(9-39)amide and a combination of both peptides on the insulin and glycaemic responses to feeding in obese hyperglycaemic $(o b / o b)$ mice, a commonly used animal model of Type 2 diabetes with marked hyperinsulinaemia due to enhanced activity of the enteroinsular axis [27].

\section{Materials and methods}

Materials. High-performance liquid chromatography (HPLC) grade acetonitrile was obtained from Rathburn (Walkersburn, Scotland, UK). Sequencing grade trifluoroacetic acid (TFA) was obtained from Aldrich (Poole, Dorset, UK). Isobutylmethylxanthine (IBMX), cAMP and ATP were all purchased from Sigma (Poole, Dorset, UK). Glucagon-like peptide-1(7-36)amide (GLP-1) was purchased from the American Peptide Company (Sunnyvale, Calif., USA) and exendin(9-39)amide was a gift from Dr A. Young (Amylin Corporation, San Diego, Calif., USA). Fmoc-protected amino acids were from Calbiochem Novabiochem (Beeston, Nottingham, UK). RPMI-1640 and DMEM tissue culture medium, foetal bovine serum, penicillin, geneticin (G145) and streptomycin were all purchased from Gibco (Paisley, Strathclyde, UK). The chromatography columns used for cAMP assay, Dowex AG 50 WX and neutral alumina AG7 were obtained from Bio-Rad (Life Science Research, Alpha Analytical, Larne, UK). All water used in these experiments was purified using a Milli-Q, Water Purification System (Milford, Mass., USA). All other chemicals used were of the highest purity available.

Peptide synthesis. GIP and $\left(\mathrm{Pro}^{3}\right)$ GIP were sequentially synthesised on an Applied Biosystems automated peptide synthesiser (model 432 A) using a standard solid-phase Fmoc procedure [28], starting from an Fmoc-Gln-Wang resin. Following cleavage from the resin by trifluoroacetic acid: water, thioanisole, ethanediol (90/2.5/5/2.5, a total volume of $20 \mathrm{ml} / \mathrm{g} \mathrm{resin})$, the resin was removed by filtration and the filtrate volume decreased under reduced pressure. Dry diethylether was slowly added until a precipitate was observed. The precipitate was collected by low-speed centrifugation, resuspended in diethyl ether and centrifuged again, the procedure was repeated five times. The resulting pellets were then dried in vacuo and judged pure by reversed-phase HPLC on a Waters Millenium 2010 chromatography system (Software version 2.1.5) and the peptides subsequently characterised using electrospray ionization-mass spectrometry (ESI-MS).

Electrospray ionization-mass spectrometry. (ESI-MS) GIP and $\left(\right.$ Pro $\left.^{3}\right)$ GIP were dissolved (approximately $400 \mathrm{pmol} / \mathrm{l}$ ) in $100 \mu \mathrm{l}$ of water and applied to an LCQ benchtop mass spectrometer (Finnigan MAT, Hemel Hempstead, UK) equipped with a microbore C-18 column $(150 \times 2.0 \mathrm{~mm}$, Phenomenex, Macclesfield, UK). Samples (20 $\mu$ l direct loop injection) were applied at a flow rate of $0.2 \mathrm{ml} / \mathrm{min}$, under isocratic conditions in $35 \%$ $(\mathrm{v} / \mathrm{v})$ acetonitrile/water. Mass spectra were obtained from the quadripole ion-trap mass analyser and spectra collected using full ion scan mode over the mass-to-charge $(\mathrm{m} / \mathrm{z})$ range 150 to 2000. The molecular masses of each fragment were calculated using prominent multiple charged ions and the following equation applied: $M_{r}=i M_{i}-i M_{h}$, where $M_{r}$ is molecular mass; $M_{i}$ is $\mathrm{m} / \mathrm{z}$ ratio; $i$ is the number of charges; and $M_{h}$ is the mass of a proton.

Cells and cell culture. Chinese hamster lung (CHL cells; ATCC CCL39) fibroblasts stably transfected with the human GIP receptor [22] were cultured in DMEM tissue culture medium containing $10 \%$ (v/v) foetal bovine serum and $1 \%(\mathrm{v} / \mathrm{v})$ antibiotics (100 U/ml penicillin, $0.1 \mathrm{mg} / \mathrm{ml}$ streptomycin). Clone 5 GLP-1 receptor transfected CHL cells were cultured as above with the exception of requiring geneticin G145 for clonal selection [17]. Insulin-secreting BRIN-BD11 cells were cultured in sterile tissue culture flasks (Corning, Glass Works, UK) using tissue culture medium RPMI-1640 containing $10 \%$ 
(v/v) foetal bovine serum, $1 \%(\mathrm{v} / \mathrm{v})$ antibiotics $(100 \mathrm{U} / \mathrm{ml}$ penicillin, $0.1 \mathrm{mg} / \mathrm{ml}$ streptomycin) and $11.1 \mathrm{mmol} / 1$ glucose [29]. The cells were maintained at $37^{\circ} \mathrm{C}$ in an atmosphere of $5 \%$ $\mathrm{CO}_{2}$ and $95 \%$ air using a LEEC incubator (Laboratory Technical Engineering, Nottingham, UK).

Effects of (Pro3)GIP and exendin(9-39)amide on GIP- and GLP-1-stimulated cAMP production in receptor-transfected CHL cells. GIP and GLP-1 receptor-transfected fibroblasts were seeded into 12-multiwell plates (Nunc, Roskilde, Denmark) at a density of $1.0 \times 10^{5}$ cells per well. The cells were cultured for a further $48 \mathrm{~h}$ before being loaded at $37^{\circ} \mathrm{C}$ for $6 \mathrm{~h}$ with $2 \mu \mathrm{Ci}$ of tritiated adenine (TRK311, Amersham, Buckinghamshire, UK) in $1 \mathrm{ml}$ DMEM supplemented with $0.5 \%$ foetal bovine serum. This was followed by two washes with HBS buffer (130 mmol/l NaCl, 20 mmol/l HEPES; pH 7.4, $0.9 \mathrm{mmol} / \mathrm{l} \mathrm{NaHPO}_{4}, 0.8 \mathrm{mmol} / 1 \mathrm{MgSO}_{4}, 5.4 \mathrm{mmol} / \mathrm{l} \mathrm{KCl}$, $1.8 \mathrm{mmol} / 1 \mathrm{CaCl}_{2}, 25 \mathrm{mmol} / \mathrm{l}$ glucose, and $25 \mu \mathrm{mol} / \mathrm{l}$ phenol red). The GIP and GLP-1 receptor-transfected cells were then exposed for $10 \mathrm{~min}$ at $37^{\circ} \mathrm{C}$ to varying concentrations $\left(10^{-12}\right.$ to $\left.10^{-6} \mathrm{~mol} / \mathrm{l}\right)$ of $\left(\mathrm{Pro}^{3}\right) \mathrm{GIP}$ or exendin(9-39)amide in the presence of $10^{-7} \mathrm{~mol} / \mathrm{l}$ GIP or GLP-1, respectively, in HBS buffer supplemented with $1 \mathrm{mmol} / \mathrm{l}$ IBMX. The medium was subsequently removed and the cells lysed with $1 \mathrm{ml}$ of $5 \%(\mathrm{v} / \mathrm{v})$ trichloroacetic acid (TCA) containing $0.1 \mathrm{mmol} / \mathrm{l}$ unlabelled cAMP and $0.1 \mathrm{mmol} / \mathrm{l}$ unlabelled ATP. The intracellular tritiated cAMP was then separated on Dowex and alumina exchange resins [30].

Effects of (Pro3)GIP and exendin(9-39)amide on GIP- and GLP-1-stimulated insulin secretion in clonal BRIN-BD11 cells. BRIN-BD11 cells were harvested with the aid of trypsin/ EDTA (Gibco, UK), seeded into 24-multiwell plates (Nunc, Roskilde, Denmark) at a density of $1.0 \times 10^{5}$ cells per well, and allowed to attach overnight at $37^{\circ} \mathrm{C}$. Acute tests for insulin release were preceded by $40 \mathrm{~min}$ pre-incubation at $37^{\circ} \mathrm{C}$ in $1.0 \mathrm{ml}$ Krebs Ringer bicarbonate buffer $(115 \mathrm{mmol} / \mathrm{l} \mathrm{NaCl}$, $4.7 \mathrm{mmol} / \mathrm{l} \mathrm{KCl}, 1.28 \mathrm{mmol} / \mathrm{CaCl}_{2}, 1.2 \mathrm{mmol} / \mathrm{l} \mathrm{KH}_{2} \mathrm{PO}_{4}$, $1.2 \mathrm{mmol} / 1 \mathrm{MgSO}_{4}, 10 \mathrm{mmol} / 1 \mathrm{NaHCO}_{3}, 0.5 \%$ (w/v) bovine serum albumin, $\mathrm{pH}$ 7.4) supplemented with $1.1 \mathrm{mmol} / \mathrm{l}$ glucose [29]. Test incubations were carried out $(n=8)$ with $5.6 \mathrm{mmol} / \mathrm{l}$ glucose over a range of concentrations $\left(10^{-12}\right.$ to $\left.10^{-6} \mathrm{~mol} / \mathrm{l}\right)$ of $\left(\mathrm{Pro}^{3}\right)$ GIP and exendin(9-39)amide with or without $10^{-7} \mathrm{~mol} / \mathrm{l}$ GIP or GLP-1. After $20 \mathrm{~min}$ incubation, the buffer was removed and stored at $-20^{\circ} \mathrm{C}$ prior to insulin radioimmunoassay (RIA).

Effects of (Pro3)GIP and exendin(9-39)amide on plasma glucose and insulin responses to feeding in obese diabetic (ob/ob) mice. Plasma glucose and insulin responses were evaluated using 14-week to 18 -week old obese diabetic $(o b / o b)$ mice. The genetic background and characteristics of the colony used have been given in detail elsewhere [31]. These mice show markedly increased plasma insulin concentrations in the fed state due to enhanced activity of the enteroinsular axis [27]. The animals were housed individually in an air-conditioned room at $22 \pm 2^{\circ} \mathrm{C}$ with a 12 -h light: 12 -h dark cycle. Drinking water and a standard rodent maintenance diet (Trouw Nutrition, Cheshire, UK) were freely available. Food was withdrawn for an 18 -h period prior to intraperitoneal (i.p.) injection $(n=8)$ of saline $\left(0.9 \%(\mathrm{w} / \mathrm{v}) \mathrm{NaCl}\right.$; control), $\left(\mathrm{Pro}^{3}\right) \mathrm{GIP}$ (25 nmol $/ \mathrm{kg}$ body weight), exendin(9-39)amide ( $25 \mathrm{nmol} / \mathrm{kg}$ body weight) or a combination of both peptides (each at $25 \mathrm{nmol} / \mathrm{kg}$ body weight). These doses will result in high concentrations of antagonist ( $\mu \mathrm{mol} / \mathrm{l})$ relative to endogenous GIP or GLP-1 (pmol/1 range) [46], and have been shown in other studies to abolish oral glucose or peptide-induced insulin increase [26, 45]. Fol- lowing injection ( $8 \mathrm{ml} / \mathrm{kg}$ body weight; final volume), the mice were allowed to re-feed for $15 \mathrm{~min}$, and the food intake monitored. Blood samples were collected from the cut tip of the tail of conscious mice into chilled fluoride/heparin glucose microcentrifuge tubes (Sarstedt, Nümbrecht, Germany) immediately prior to injection and at 15, 30, 60 and 120 min post-injection. Blood samples were immediately centrifuged using a Beckman microcentrifuge (Beckman Instruments, UK) for $30 \mathrm{~s}$ at $13000 \mathrm{~g}$ and plasma subsequently aliquoted and stored at $-20^{\circ} \mathrm{C}$ prior to glucose and insulin determinations.

Effects of (Pro3)GIP and exendin(9-39)amide on hyperinsulinaemia of non-fasted (ob/ob) mice. Acute effects of ( $\left.\mathrm{Pro}^{3}\right) \mathrm{GIP}$ and exendin(9-39)amide on basal hyperinsulinaemia of fed $(o b / o b)$ mice were evaluated by i.p. injection $(n=8)$ of saline, $\left(\mathrm{Pro}^{3}\right)$ GIP, exendin(9-39)amide or a combination of both peptides. Food was withheld during the tests and blood samples were collected immediately prior to and at 15, 30, 60 and $120 \mathrm{~min}$ after injection. Plasma was aliquoted and stored at $-20^{\circ} \mathrm{C}$ for subsequent glucose and insulin determinations. All animal studies were carried out in accordance with the UK Animals (Scientific Procedures) Act 1986.

Analytical methods. Plasma glucose was assayed by an automated glucose oxidase procedure using a Beckman Glucose Analyzer II [32] and insulin was measured by dextran-coated charcoal RIA [33]. Incremental areas under plasma glucose and insulin curves (AUC) were calculated using a computergenerated program (CAREA) using the trapezoidal rule [34] with baseline subtraction where appropriate. Results are expressed as means \pm SEM and data compared using the Student's $t$ test or ANOVA, followed by the Student-NewmanKeuls post hoc test, as appropriate. A $p$ value of less than 0.05 was considered statistically significant.

\section{Results}

Structural identification of GIP and (Pro3)GIP by ESI$M S$. GIP and $\left(\right.$ Pro $\left.^{3}\right)$ GIP were synthesised by solidphase Fmoc peptide synthesis and further purified using a Vydac C-18 analytical column $(4.6 \times 250 \mathrm{~mm})$. Figure 1 shows the monoisotopic molecular masses obtained for GIP (A) and ( $\left.\mathrm{Pro}^{3}\right)$ GIP (B) after spectral averaging was carried out. Prominent multiple charged species $(\mathrm{M}+3 \mathrm{H})^{3+}$ and $(\mathrm{M}+4 \mathrm{H})^{4+}$ were detected from GIP at $\mathrm{m} / \mathrm{z} 1661.6$ and 1246.8 , corresponding to intact $\mathrm{M}_{\mathrm{r}} 4981.8$ and 4983.2, respectively (Fig. 1A). This corresponds very closely with the theoretical mass of 4980.5. For $\left(\mathrm{Pro}^{3}\right) \mathrm{GIP},(\mathrm{M}+3 \mathrm{H})^{3+}$ and $(\mathrm{M}+4 \mathrm{H})^{4+}$ were detected at $\mathrm{m} / \mathrm{z} 1650.8$ and 1238.6 , corresponding to intact molecular masses of $\mathrm{M}_{\mathrm{r}} 4949.4$ and 4950.4, respectively (Fig. 1B), corresponding very closely with the theoretical mass of 4948.5 .

Inhibition of GIP- and GLP-1-stimulated cAMP production by (Pro3)GIP and exendin(9-39)amide. Only very weak stimulation of cAMP stimulation was observed when $10^{-12}$ to $10^{-6} \mathrm{~mol} / \mathrm{l}$ of either $\left(\mathrm{Pro}^{3}\right)$ GIP or exendin(9-39)amide were applied to fibroblasts stably transfected with the human GIP receptor (9-12\% increase). In contrast, both $\left(\mathrm{Pro}^{3}\right) \mathrm{GIP}$ and exendin(9-39)amide were able to concentration-dependent- 


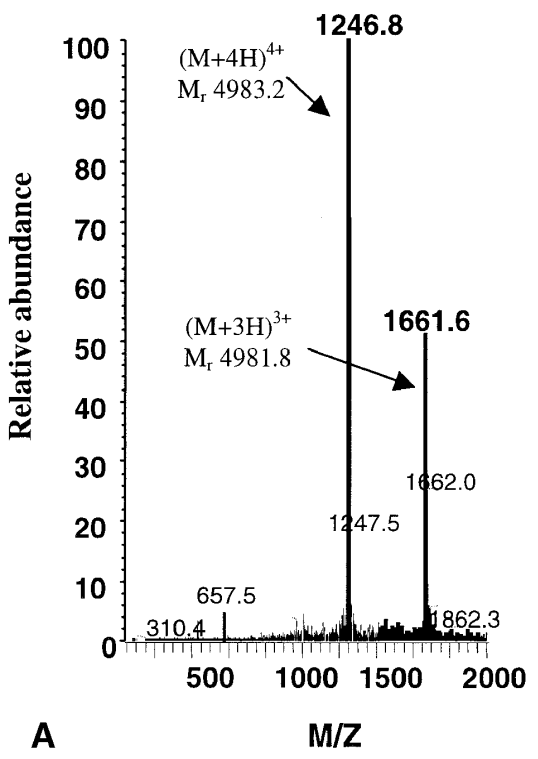

Fig. 1A, B. Electrospray ionization-mass spectrometry (ESIMS) of (A) GIP and (B) $\left(\right.$ Pro $\left.^{3}\right)$ GIP. Samples $(20 \mu$ l) were applied to a LC/MS equipped with a microbore C-18 HPLC column $(150 \times 2.0 \mathrm{~mm})$. Spectra were recorded using a quadripole ion-trap mass analyser and collected using full ion scan mode over the mass-to-charge $(\mathrm{m} / \mathrm{z})$ ratio $150-2000$

ly inhibit cAMP production by cells exposed to stimulatory GIP $\left(10^{-7} \mathrm{~mol} / \mathrm{l}\right)$. cAMP production was inhibited by $22.0 \pm 0.7 \%$ [( Pro $\left.\left.^{3}\right) \mathrm{GIP}\right]$ and $17.5 \pm 0.35 \%$ [exendin(9-39)amide] and by $70.0 \pm 3.5 \%\left[\left(\mathrm{Pro}^{3}\right) \mathrm{GIP}\right]$ and $73.5 \pm 3.2 \%$ [exendin(9-39)amide] at peptide concentrations of $10^{-8}$ and $10^{-6} \mathrm{~mol} / \mathrm{l}$, respectively (Fig. 2A).

In CHL cells stably transfected with the GLP-1 receptor, exendin(9-39)amide $\left(10^{-12}\right.$ to $\left.10^{-6} \mathrm{~mol} / \mathrm{l}\right)$ inhibited GLP-1 (10 $\left.10^{-7} \mathrm{~mol} / \mathrm{l}\right)$-stimulated cAMP production by $45.5 \pm 0.3 \%$ and $60.0 \pm 0.7 \%$ at peptide concentrations of $10^{-8}$ and $10^{-6} \mathrm{~mol} / \mathrm{l}$, respectively (Fig. 2B). Consistent with the specificity of $\left(\mathrm{Pro}^{3}\right)$ GIP for the GIP receptor, $\left(\mathrm{Pro}^{3}\right)$ GIP had no effect on GLP-1-stimulated cAMP formation (Fig. 2B).

Actions of (Pro3)GIP and exendin(9-39)amide on GIP- and GLP-1-stimulated insulin secretion. $\left(\right.$ Pro $\left.^{3}\right)$ GIP $\left(10^{-12}\right.$ to $\left.10^{-6} \mathrm{~mol} / \mathrm{l}\right)$ did not affect basal insulin secretion recorded at $5.6 \mathrm{mmol} / \mathrm{l}$ glucose alone. In contrast, $\left(\right.$ Pro $\left.^{3}\right)$ GIP inhibited insulin release stimulated by $10^{-7} \mathrm{~mol} / \mathrm{l}$ native GIP by up to $86 \%(p<0.001)$ in a concentration-dependent manner. $\left(\mathrm{Pro}^{3}\right) \mathrm{GIP}$ did not affect insulin secretion stimulated by $10^{-7} \mathrm{~mol} / \mathrm{l}$ GLP-1 (Fig. 3A).

Exendin(9-39)amide similarly did not affect basal insulin secretion at $5.6 \mathrm{mmol} / \mathrm{l}$ glucose. With stimulatory $10^{-7} \mathrm{~mol} / \mathrm{l}$ GLP-1, exendin(9-39)amide $\left(10^{-12}\right.$ to $10^{-6} \mathrm{~mol} / \mathrm{l}$ ) inhibited insulin release by up to $44 \%$ $(p<0.001)$. Exendin(9-39)amide also inhibited insulin release in a concentration-dependent manner by up to $57 \%$ $(p<0.001)$ induced by $10^{-7} \mathrm{~mol} / \mathrm{l} \mathrm{GIP}$ alone (Fig. 3B).

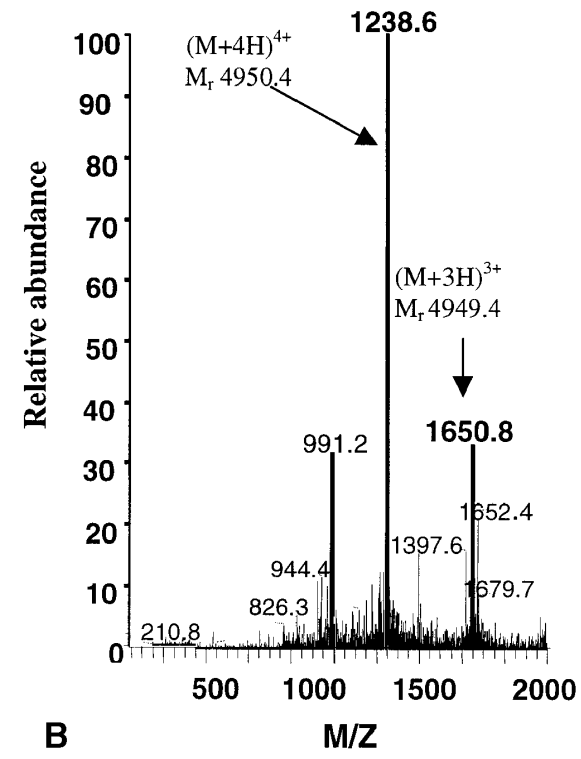

Effects of (Pro3)GIP and exendin(9-39)amide on metabolic responses to feeding in (ob/ob) mice. Food intake was similar in the four groups [saline control $0.3 \pm 0.1 \mathrm{~g} / \mathrm{mouse} / 15 \mathrm{~min}$; $\left(\mathrm{Pro}^{3}\right) \mathrm{GIP}$ only-treated $0.2 \pm 0.1 \mathrm{~g} / \mathrm{mouse} / 15 \mathrm{~min}$; exendin(9-39)amide onlytreated $0.3 \pm 0.1 \mathrm{~g} / \mathrm{mouse} / 15 \mathrm{~min}$; $\left(\right.$ Pro $\left.^{3}\right)$ GIP and exendin(9-39)amide-treated $0.2 \pm 0.1 \mathrm{~g} /$ mouse $/ 15 \mathrm{~min}$; values are means \pm SEM, $n=8]$. The mean fasting plasma glucose concentration in control mice increased from $5.0 \pm 0.5$ to peak at $21.6 \pm 0.7 \mathrm{mmol} / \mathrm{l}$ by $15 \mathrm{~min}$ (Fig. $4 \mathrm{~A}$ ). The administration of exendin(9-39)amide resulted in higher plasma glucose concentrations at 60 and $120 \mathrm{~min}$ (1.2-fold to 1.4-fold; $p<0.05$ to $p<0.01)$. In contrast, glucose concentrations of mice receiving $\left(\mathrm{Pro}^{3}\right) \mathrm{GIP}$ or a combination of both peptides were not different from saline-treated controls. No significant differences were observed between the antagonist-treated groups. Furthermore, glucose AUC data showed that administration of exendin(9-39)amide alone raised plasma glucose concentrations by $27 \%(p<0.05)$ during the test while $\left(\mathrm{Pro}^{3}\right)$ GIP or a combination of both peptides did not when compared with saline control mice (Fig. 4B).

Plasma insulin responses to feeding showed much clearer differences with a lowered insulinotropic activity among the antagonist-treated mice (Fig. 5A). Plasma insulin concentrations of control mice increased from a fasting level of $3.1 \pm 0.4$ to peak at $13.4 \pm 0.8 \mathrm{ng} / \mathrm{ml}$ by $15 \mathrm{~min}$ (Fig. $5 \mathrm{~A}$ ). The administration of ( Pro $\left.^{3}\right)$ GIP, exendin(9-39)amide, or a combination of both peptides decreased $(p<0.05$ to $p<0.01)$ plasma insulin levels by 19,28 , and $23 \%$ at $15 \mathrm{~min}$ and by 49,57 and $52 \%$, respectively, at $120 \mathrm{~min}$ $(p<0.01$ to $p<0.001)$ when compared to control mice. No differences were detected between the antagonisttreated groups. The overall responses of AUC insulin showed that $\left(\right.$ Pro $\left.^{3}\right)$ GIP, exendin(9-39)amide or a combination of both peptides decreased $(p<0.01$ to $p<0.001$ ) plasma insulin concentrations by 42,54 and $49 \%$, respectively, when compared with the saline- 
A

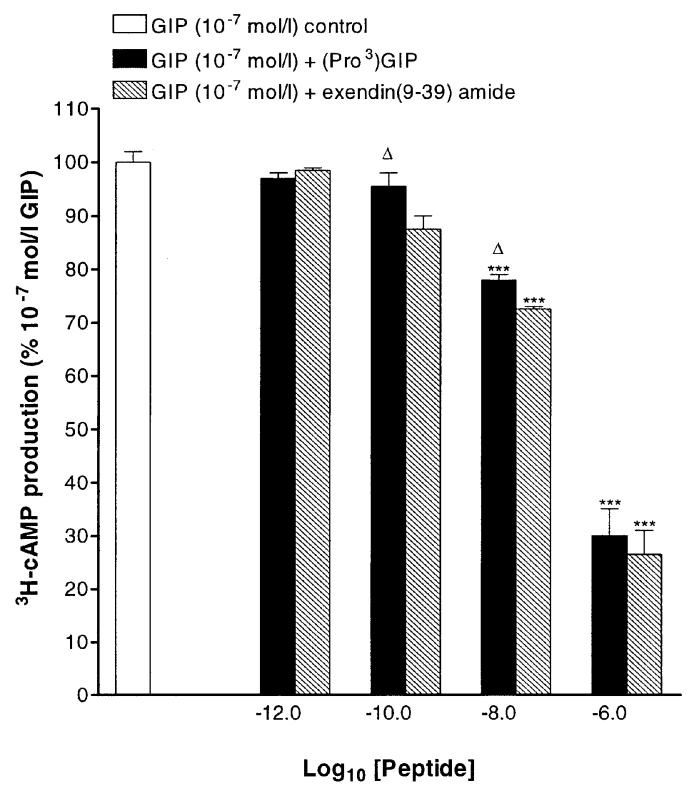

B

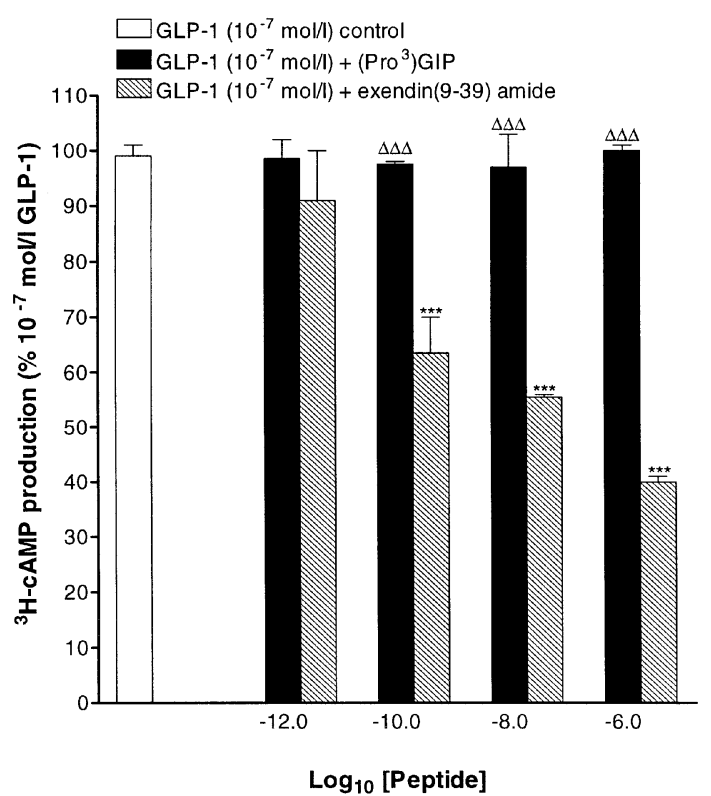

Fig. 2A, B. Effects of $\left(\right.$ Pro $\left.^{3}\right)$ GIP and exendin(9-39)amide on incretin-induced cAMP production in receptor-transfected CHL cells. Stably transfected GIP (A) and GLP-1 (B) receptor fibroblasts were incubated with $10^{-12}$ to $10^{-6} \mathrm{~mol} / \mathrm{l}\left(\mathrm{Pro}^{3}\right) \mathrm{GIP}$ or exendin(9-39)amide in the presence of either stimulatory $\left(10^{-7} \mathrm{~mol} / \mathrm{l}\right)$ GIP or GLP-1, respectively. Values represent the means \pm SEM of three independent experiments. ${ }^{* * *} p<0.001$ compared with GIP/GLP-1 $\left(10^{-7} \mathrm{~mol} / \mathrm{l}\right)$ control. ${ }^{\Delta} p<0.05$, ${ }^{\Delta \Delta \Delta} p<0.001$ between peptides under the same conditions

treated controls (Fig. 5B). Again no differences were observed between the antagonist-treated groups.

Effects of (Pro3)GIP and exendin(9-39)amide on hyperinsulinaemia of non-fasted (ob/ob) mice. The changes in circulating insulin concentrations of non-
A

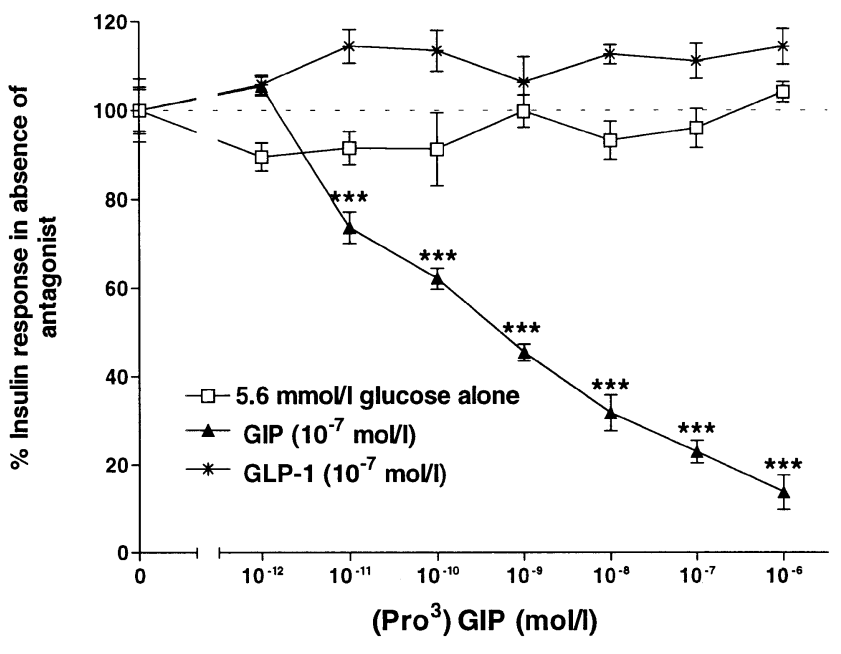

B

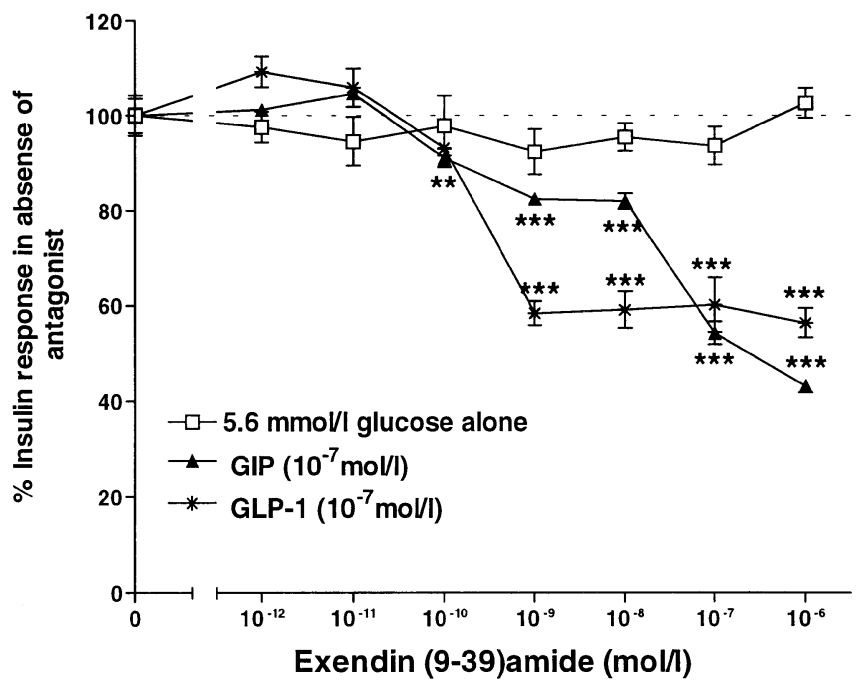

Fig. 3A, B. Effects of $\left(\right.$ Pro $\left.^{3}\right)$ GIP and exendin(9-39)amide on GIP- and GLP-1-stimulated insulin secretion in clonal pancreatic BRIN-BD11 cells. Insulin releasing activities of $\left(\mathrm{Pro}^{3}\right) \mathrm{GIP}$ (A) and exendin(9-39)amide (B) with or without $10^{-7} \mathrm{~mol} / \mathrm{l}$ GIP and GLP-1 were tested during a 20 min incubation period. Data are shown as \% of insulin response observed without antagonist. Values are means \pm SEM for eight observations. ${ }^{* *} p<0.01,{ }^{* * *} p<0.001$ compared with $5.6 \mathrm{mmol} / \mathrm{l}$ control

fasted $(o b / o b)$ mice following i.p. administration of $\left(\right.$ Pro $\left.^{3}\right)$ GIP, exendin(9-39)amide or a combination of both peptides are shown (Fig. 6). In the fed state, these animals exhibited insulin concentrations of 24 to $31 \mathrm{ng} / \mathrm{ml}$. After injection of $\left(\right.$ Pro $\left.^{3}\right) \mathrm{GIP}$, exendin(9-39)amide or a combination of both peptides insulin concentrations were lowered $(8-35 \% ; p<0.05$ to $p<0.001)$ at 15 to 120 min post-injection compared with the saline control group (Fig. 6A). A small decrease of plasma insulin was observed in the salinetreated group, reflecting withdrawal of food for the 

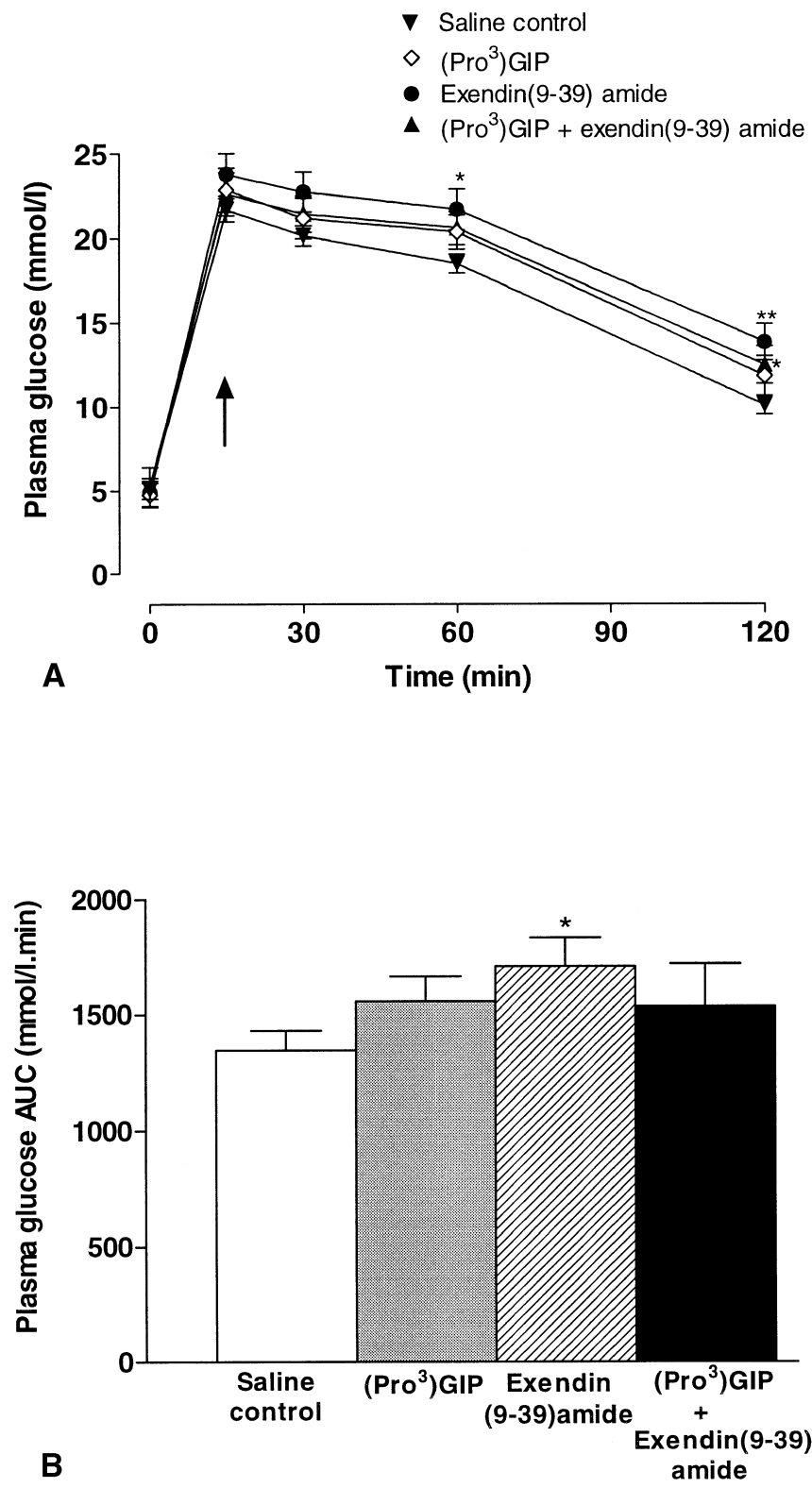

Fig. 4A, B. Effects of $\left(\right.$ Pro $\left.^{3}\right)$ GIP and exendin(9-39)amide on plasma glucose concentrations in response to feeding in 18-h fasted $(o b / o b)$ mice. (A) Plasma glucose concentrations of mice allowed to re-feed for 15 min prior to i.p. administration of saline $(0.9 \%(\mathrm{w} / \mathrm{v}) \mathrm{NaCl})$ as control, $\left(\mathrm{Pro}^{3}\right) \mathrm{GIP}(25 \mathrm{nmol} / \mathrm{kg}$ body weight), exendin(9-39)amide $(25 \mathrm{nmol} / \mathrm{kg})$ or a combination of both peptides (each at $25 \mathrm{nmol} / \mathrm{kg}$ ). The time of injection is indicated by the arrow $(15 \mathrm{~min})$. (B) Plasma glucose AUC values for 0-120 min. Values are means \pm SEM for eight mice. ${ }^{*} p<0.05,{ }^{* *} p<0.01$, compared with saline alone

duration of the test. AUC insulin was lowered $(p<0.05$ to $p<0.01)$ by $\left(\mathrm{Pro}^{3}\right) \mathrm{GIP}$, exendin(9-39)amide or a combination of both peptides compared to the saline control mice $(20 \%, 27 \%$ and $19 \%$, respectively) (Fig. 6B). No differences were observed between the antagonist-treated groups. Plasma glucose concentrations were unchanged during the test period and did not differ between the treatment groups.
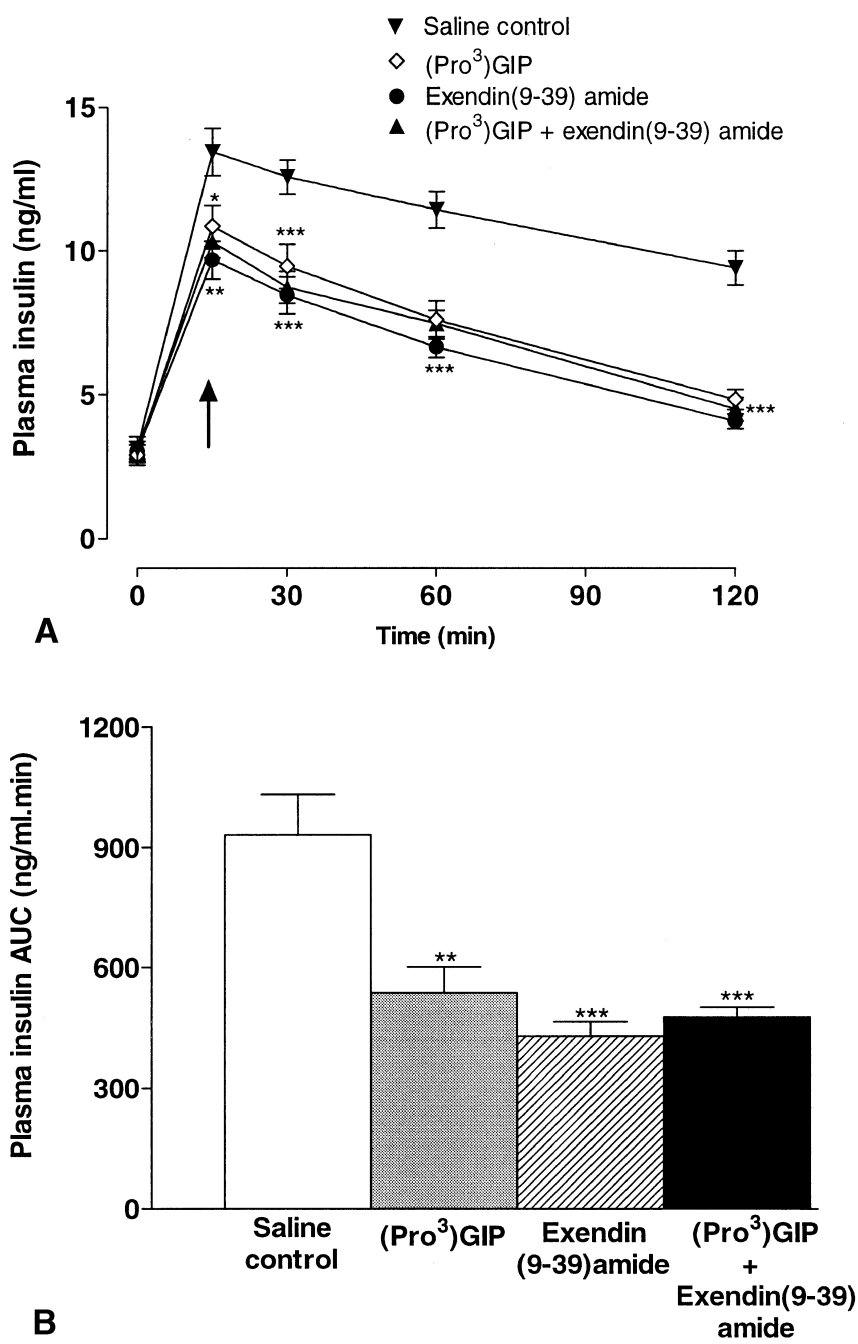

Fig. 5A, B. Effects of $\left(\right.$ Pro $\left.^{3}\right)$ GIP and exendin(9-39)amide on plasma insulin responses to feeding in 18-h fasted $(o b / o b)$ mice. (A) Plasma insulin concentrations of mice allowed to refeed for $15 \mathrm{~min}$ prior to i.p. administration of saline $(0.9 \%$ $(\mathrm{w} / \mathrm{v}) \mathrm{NaCl}$ ) as control, ( Pro $\left.^{3}\right) \mathrm{GIP}(25 \mathrm{nmol} / \mathrm{kg}$ body weight), exendin(9-39)amide $(25 \mathrm{nmol} / \mathrm{kg})$ or a combination of both peptides (each at $25 \mathrm{nmol} / \mathrm{kg}$ ). The time of injection is indicated by the arrow (15 min). (B) Plasma insulin AUC values for $0-120 \mathrm{~min}$. Values are means \pm SEM for eight mice. ${ }^{*} p<0.05$, ${ }^{* *} p<0.01,{ }^{* * *} p<0.001$ compared with saline alone

\section{Discussion}

Glucose-dependent insulinotropic polypeptide (GIP) and glucagon-like peptide-1 (GLP-1) are widely regarded as important incretin hormones of the enteroinsular axis $[35,36]$. This study has used the novel $\left(\mathrm{Pro}^{3}\right)$ GIP antagonist [26] and exendin(9-39)amide [17] to evaluate the relative roles of these two incretin hormones.

As expected from previous studies in GIP receptortransfected cells [22, 23], GIP markedly stimulated cAMP production, whereas $\left(\mathrm{Pro}^{3}\right) \mathrm{GIP}$ exerted only very weak effects. Exendin(9-39)amide similarly lacked significant effects on cAMP production in GIP receptor-transfected cells. However, both $\left(\mathrm{Pro}^{3}\right) \mathrm{GIP}$ 

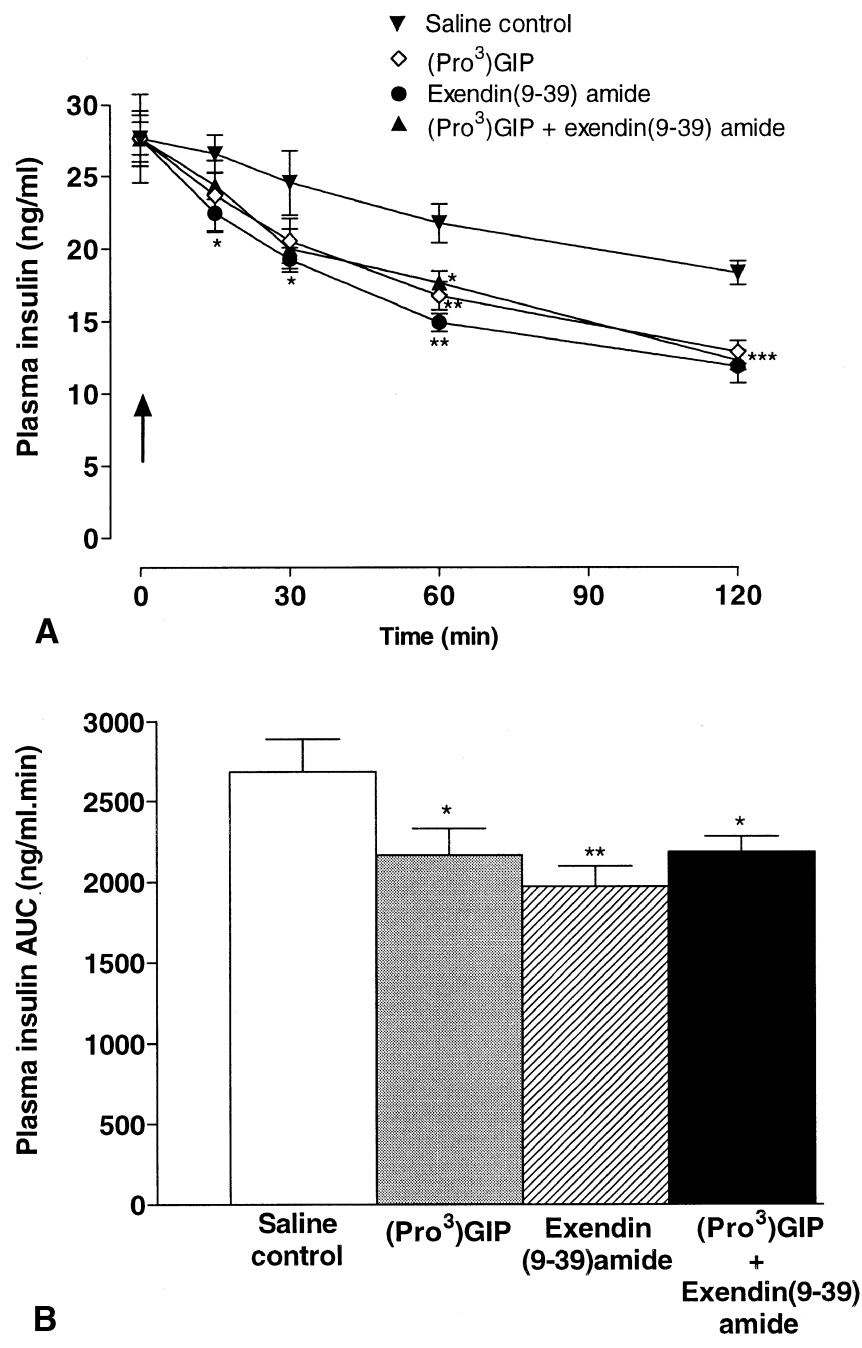

Fig. 6A, B. Effects of $\left(\right.$ Pro $\left.^{3}\right)$ GIP and exendin(9-39)amide on plasma insulin concentrations in non-fasted $(o b / o b)$ mice. (A) Plasma insulin concentrations after i.p. administration of saline $(0.9 \%(\mathrm{w} / \mathrm{v}) \mathrm{NaCl})$ as control, $\left(\mathrm{Pro}^{3}\right) \mathrm{GIP}(25 \mathrm{nmol} / \mathrm{kg}$ body weight), exendin(9-39)amide $(25 \mathrm{nmol} / \mathrm{kg})$ or a combination of both peptides (each at $25 \mathrm{nmol} / \mathrm{kg}$ ). The time of injection is indicated by the arrow $(0 \mathrm{~min})$. Food was withheld during the test. (B) Plasma insulin AUC values for 0-120 min. Values are means \pm SEM for eight mice. ${ }^{*} p<0.05,{ }^{*} p<0.01$, ${ }^{* * * *} p<0.001$ compared with saline alone

and the GLP-1 receptor antagonist exendin(9-39)amide inhibited GIP-stimulated cAMP production in a concentration-dependent manner, by up to $70 \%$ and $73 \%$, respectively. These observations corroborate previous findings, where exendin(9-39)amide effectively antagonised the effects of a stimulatory concentration of native GIP [22]. In GLP-1 receptor-transfected fibroblasts, exendin(9-39)amide effectively inhibited GLP-1-stimulated cAMP production by up to $60 \%$. $\left(\mathrm{Pro}^{3}\right)$ GIP, however, had no effect on GLP-1-stimulated cAMP production, therefore confirming the analogue's specificity for the GIP receptor. Thus, the results of earlier studies [16, 18, 19], which have relied on exendin(9-39)amide being specific for only the
GLP-1 receptor, should be interpreted with caution, especially with respect to the relative contribution of GLP-1 to the enteroinsular axis.

In clonal BRIN-BD11 cells, (Pro $\left.{ }^{3}\right)$ GIP acted as a potent inhibitor of GIP-induced insulin secretion with $86 \%$ maximal inhibition. This effect was specific as $\left(\mathrm{Pro}^{3}\right)$ GIP did not affect GLP-1-stimulated insulin secretion and confirmed observations in GLP-1 receptortransfected cells. As predicted [17], exendin(9-39)amide inhibited the stimulatory action of GLP-1 with maximal $44 \%$ inhibition. However, in keeping with observations in GIP receptor-transfected cells, exendin(9-39)amide also inhibited GIP-induced insulin secretion by up to $57 \%$. Together these combined in vitro data show that both (Pro ${ }^{3}$ GIP and exendin(9-39)amide act as GIP receptor antagonists, effectively inhibiting GIP-stimulated insulin release and cAMP production. Unlike exendin(9-39)amide, $\left(\mathrm{Pro}^{3}\right)$ GIP is a specific antagonist and does not interfere with the actions of the sister incretin hormone, GLP-1.

While GLP-1 seems to be a more potent insulin secretagogue than GIP, the rise in serum GIP levels following an oral glucose load is much greater than the increment in plasma GLP-1 $[37,38]$. GIP also seems to have a slightly longer half-life, although both peptides are cleaved by DPP IV to inactive metabolites, which circulate in high amounts not distinguished from intact GIP or GLP-1 by most RIA's [39, 40, 41, 42, 43]. In this study, administration of $\left(\mathrm{Pro}^{3}\right) \mathrm{GIP}$ or exendin(9-39)amide to $(o b / o b)$ mice reduced meal-induced insulin release by $42 \%$ and $54 \%$, respectively. Administration of both antagonists together decreased the insulin response by $49 \%$ with no additive effect. Although some caution is necessary, these data suggest that exendin(9-39) amide abolished the full incretin effect and that GIP accounts for approximately $80 \%$ of incretininduced insulin secretion. This is consistent with the ability of exendin(9-39)amide to strongly inhibit GIPstimulated insulin secretion from BRIN-BD11 cells at $10^{-7} \mathrm{~mol} / \mathrm{l}$, a concentration likely to be well exceeded following distribution of $25 \mathrm{nmol} / \mathrm{kg}$ peptide into the small extracellular compartment of (ob/ob) mice. Associated with the antagonist-induced reduction of mealinduced insulin release, glycaemic responses were only modestly increased reflecting the severe insulin resistance of this mutant. The relatively greater glycaemic response following exendin(9-39)amide administration might reflect antagonism of the extrapancreatic actions of GLP-1, such as stimulation of glucose transport in muscle and inhibition of gastric emptying [5]. Consistent with the major contribution of GIP to the enteroinsular axis of these mice [27], administration of $\left(\mathrm{Pro}^{3}\right)$ GIP, exendin(9-39)amide or a combination of both peptides lowered the hyperinsulinaemia of fed $(o b / o b)$ mice by 20, 27 and 19\%, respectively. Combination of both antagonists had no additive effect again suggesting that exendin(9-39)amide blocks both GLP-1 and GIP-induced insulin release. 
In previous studies where exendin(9-39)amide was administered to rats, postprandial insulin release was reduced by $50-70 \%[16,18]$. Other studies concluded that the incretin effects of GIP and GLP-1 account for greater than $50 \%$ of meal-induced insulin release, with the insulin response decreased by $72 \%$ following administration of the GIP receptor-antagonist, GIP(7-30)$\mathrm{NH}_{2}$ (ANTGIP), to chow-fed rats [44, 45]. These values are broadly in line with our study. However, since the GLP-1 receptor-antagonist, exendin(9-39)amide is non-specific $[22,23]$, care must be taken not to overestimate the importance of GLP-1. Thus exendin(9-39)amide is also a potent inhibitor of GIP-stimulated insulin release at concentrations achieved following administration of high doses of the antagonist in vivo. Therefore, GIP contributes significantly more to the enteroinsular axis than has recently been thought and is likely to be the major physiological incretin.

In conclusion, this study indicates that $\left(\mathrm{Pro}^{3}\right) \mathrm{GIP}$ is a specific receptor antagonist of GIP, whereas exendin(9-39)amide counters both GLP-1 and GIP receptor-mediated actions. In vivo studies with a commonly used animal model of obesity-diabetes and enteroendocrine hyperactivity show that both GIP and GLP-1 play an important role in mediating postprandial insulin release. However, GIP is the major physiological incretin accounting for approximately $80 \%$ of nutrient-induced enteroinsular pancreatic beta-cell stimulation.

Acknowledgements. These studies were supported by the Department of Health and Personal Social Services for Northern Ireland and University of Ulster Research Strategy Funding. The authors wish to thank Professor B. Thorens (University of Lausanne, Switzerland) for kindly providing transfected CHL cells and Dr CJ Bailey (Aston University, Birmingham, UK) for $(o b / o b)$ mice.

\section{References}

1. Ahrén B, Karlsson S (1994) Role of islet neuropeptides in the regulation of insulin secretion. In: PR Flatt, S Lenzen (eds) Frontiers of Insulin Secretion and Pancreatic B-cell Research. Smith-Gordon, London, pp 313-318

2. Flatt PR (1996) Pancreatic B-cells as mediators of metabolic effects of regulatory peptides. Biochem Soc Trans 24: 570-575

3. Morgan LM (1996) The metabolic role of GIP: physiology and pathology. Biochem Soc Trans 24:585-591

4. Dupré J, Ross SA, Watson D, Brown JC (1973) Stimulation of insulin secretion by gastric inhibitory polypeptide in man. J Clin Endocrinol Metab 81:826-828

5. Brown JC (1994) Enteroinsular axis. In: JH Walsh, GJ Dockray (eds) Gut peptides: biochemistry and physiology. Raven Press, New York, pp 765-784

6. Holst JJ (1994) Glucagon-like peptide 1: a newly discovered gastrointestinal hormone. Gastroenterology 107:1848-1855

7. Gutniak M, Ørskov C, Holst JJ et al. (1992) Antidiabetic effect of glucagon-like peptide-1 (7-36) amide in normal subjects and patients with diabetes. N Engl J Med 326: 1316-1322
8. Nauck MA, Holst JJ, Willms B, Schmiegel W (1997) Glucagon-like peptide-1 (GLP-1) as a new therapeutic approach for type 2 diabetes. Exp Clin Endocrinol Diabetes 105:187-195

9. O'Harte FPM, Abdel-Wahab YHA, Conlon JM, Flatt PR (1998) Amino terminal glycation of gastric inhibitory polypeptide enhances its insulinotropic action on clonal pancreatic B-cells. Biochim Biophys Acta 1425:319-327

10. O'Harte FPM, Mooney MH, Kelly CMN, Flatt PR (2000) Improved glycaemic control in obese diabetic ob/ob mice using N-terminally modified gastric inhibitory polypeptide. J Endocrinol 165:639-648

11. Schmid R, Schusdziarra V, Aulehner R et al. (1990) Comparison of GLP-1 (7-36 amide) and GIP on release of somatostatin-like immunoreactivity and insulin release from the isolated rat pancreas. Gastroenterology 28:280-284

12. Suzuki S, Kawai K, Oshashi S et al. (1990) Reduced insulinotropic effects of glucagon-like peptide-1-(7-36) amide and gastric inhibitory polypeptide in isolated perfused diabetic rat pancreas. Diabetes 39:1320-1325

13. Shima K, Hirota M, Ohboshi C (1988) Effect of glucagonlike peptide-1 on insulin secretion. Regul Pept 22:245-252

14. Siegel EG, Schulze A, Schmidt WE, Creutzfeldt WE (1992) Comparison of the effect of GIP and GLP-1 (7-36)amide on insulin release from rat pancreatic islets. Eur J Clin Invest 22:154-157

15. Eng J, Kleinman WA, Singh L et al. (1992) Isolation and characterization of exendin-4, an exendin-3 analogue, from heloderma suspectum venom. Further evidence for an exendin receptor on dispersed acini from guinea pig pancreas. J Biol Chem 267:7402-7405

16. Wang Z, Wang RM, Owji AA et al. (1995) Glucagon like peptide- 1 is a physiological incretin in rat. J Clin Invest 95: $417-421$

17. Thorens B, Porret A, Bühler L et al. (1993) Cloning and functional expression of the human islet GLP-1 receptor. Demonstration that exendin-4 is an agonist and exendin (9-39) an antagonist of the receptor. Diabetes 42: $1678-1682$

18. Kolligs F, Fehmann HC, Göke R, Göke B (1995) Reduction of the incretin effect in rats by the glucagon-like peptide receptor antagonist exendin (9-39) amide. Diabetes 44:16-19

19. D’Alessio DA, Vogel R, Prigeon R et al. (1996) Elimination of the action of glucagon-like peptide 1 causes an impairment of glucose tolerance after nutrient ingestion by healthy baboons. J Clin Invest 97:133-138

20. Schirra J, Sturm K, Leicht P et al. (1998) Exendin (9-39)amide is an antagonist of glucagon-like peptide-1 (7-36)amide in humans. J Clin Invest 101:1421-1430

21. Edwards CMB, Todd JF, Mahmoudi M et al. (1998) Glucagon-like peptide 1 has a physiological role in the control of postprandial glucose in humans. Diabetes 48:86-93

22. Gremlich S, Porret A, Hani EH et al. (1995) Cloning, functional expression, and chromosomal localization of the human pancreatic islet glucose-dependent insulinotropic polypeptide receptor. Diabetes 44:1202-1208

23. Wheeler MB, Gelling RW, McIntosh CHS et al. (1995) Functional expression of the rat pancreatic islet glucose-dependent insulinotropic polypeptide receptor: ligand binding and intracellular signalling properties. Endocrinology 136: 4629-4639

24. Pederson RA, Satkunarajah M, McIntosh CHS et al. (1998) Enhanced glucose-dependent insulinotropic polypeptide secretion and insulinotropic action in glucagon like peptide 1 receptor -/- mice. Diabetes 47:1046-1052 
25. Miyawaki K, Yamada Y, Yano H et al. (1999) Glucose intolerance caused by a defect in the entero insular axis: a study in gastric inhibitory polypeptide receptor knockout mice. Proc Natl Acad Sci USA 96:14843-14847

26. Gault VA, O'Harte FPM, Harriott P, Flatt PR (2002) Characterization of the cellular and metabolic effects of a novel enzyme-resistant antagonist of glucose-dependent insulinotropic polypeptide. Biochem Biophys Res Commun 290: 1420-1426

27. Bailey CJ, Flatt PR (2003) Animal syndromes of non-insulin dependent diabetes mellitus. In: J Pickup, G Williams (eds) Textbook of diabetes, 3rd edn. Blackwell Scientific Publications, Oxford, pp 25.1-25.3

28. Fields GB, Noble RL (1990) Solid phase peptide synthesis utilizing 9-fluorenylmethoxycarbonyl amino acids. Int J Pept Protein Res 35:161-214

29. McClenaghan NH, Barnett CR, Ah-Sing E et al. (1996) Characterization of a novel glucose responsive insulinsecreting cell line, BRIN-BD11, produced by electrofusion. Diabetes 45:1132-1140

30. Widmann C, Bürki E, Dolci W, Thorens B (1993) Signal transduction by the cloned glucagon-like peptide- 1 receptor: comparison with signalling by the endogenous receptors of $\beta$-cell lines. Mol Pharmacol 45:1029-1035

31. Bailey CJ, Flatt PR (1982) Influence of genetic background and age on the expression of obese hyperglycaemic syndrome in Aston ob/ob mice. Int J Obes ity 6:11-22

32. Stevens JF(1971) Determination of glucose by an automatic analyser. Clin Chim Acta 32:199-201

33. Flatt PR, Bailey CJ (1981) Abnormal plasma glucose and insulin responses in heterozygous lean $(\mathrm{ob} /+)$ mice. Diabetologia 20:573-577

34. Burington RS (1973) Handbook of mathematical tables and formulas. McGraw-Hill, New York

35. Elahi D, Andersen DK, Brown JC et al. (1979) Pancreatic $\alpha$ - and $\beta$-cell responses to GIP infusion in normal man. Am J Physiol 237:185-191

36. Pederson RA (1994) Gastric inhibitory polypeptide. In: JH Walsh, GJ Dockray (eds) Gut peptides: biochemistry and physiology. Raven Press, New York, pp 217-259

37. Elliott RM, Morgan LM, Tredger JA et al. (1993) Glucagon like peptide-1(7-36)amide and glucose-dependent insulinotropic polypeptide secretion in response to nutrient ingestion in man: acute post prandial and 24-h secretion patterns. J Endocrinol 138:159-166
38. Nauck MA, Bartels E, Ørskov C et al. (1993) Additive insulinotropic effects of exogenous synthetic human gastric inhibitory polypeptide and glucagon like peptide-1-(7-36) amide infused at near physiological insulinotropic hormone and glucose concentrations. J Clin Endocrinol Metab 76: 912-917

39. Deacon CF, Nauck MA, Toft-Nielsen M et al. (1995) Both subcutaneously and intravenously administered glucagonlike peptide- 1 are rapidly degraded from the NH2-terminus in type II diabetic patients and in healthy subjects. Diabetes 44:1126-1131

40. Kieffer TJ, McIntosh CHS, Pederson RA (1995) Degradation of glucose-dependent insulinotropic polypeptide and truncated glucagon-like peptide 1 in vitro and in vivo by dipeptidyl peptidase IV. Endocrinology 136:35853596

41. Pauly RP, Rosche F, Wermann M et al. (1996) Investigation of glucose-dependent insulinotropic polypeptide(1-42) and glucagon like-peptide-1-(7-36) degradation in vitro by dipeptidyl peptidase IV using matrix assisted laser desorption-time of flight mass spectrometry: a novel kinetic approach. J Biol Chem 271:23222-23229

42. Deacon CF, Nauck MA, Meier J et al. (2000) Degradation of endogenous and exogenous gastric inhibitory polypeptide (GIP) in healthy and in type 2 diabetic subjects as revealed using a new assay for the intact peptide. J Clin Endocrinol Metab 85:3575-3581

43. Deacon CF, Danielsen P, Klarskov L et al. (2001) Dipeptidyl peptidase IV inhibition reduces the degradation and clearance of GIP and potentiates its insulinotropic and antihyperglycaemic effects in anesthetized pigs. Diabetes 50:1588-1597

44. Tseng C-C, Kieffer TJ, Jarboe LA et al. (1996) Postprandial stimulation of insulin release by glucose-dependent insulinotropic polypeptide (GIP). Effect of a specific glucosedependent insulinotropic polypeptide receptor antagonist in the rat. J Clin Invest 98:2440-2445

45. Tseng C-C, Zhang X-Y, Wolfe M (1999) Effect of GIP and GLP-1 antagonists on insulin release in the rat. Am J Physiol 276: E1049-E1054

46. Vilsbøll T, Krarup T, Deacon CF, Madsbad S, Holst JJ (2001) Reduced postprandial concentrations of intact biologically active glucagon-like peptide 1 in type 2 diabetic patients. Diabetes 50:609-613 